\title{
LEAD Mexico: Insights from Insider and Outsider Interviews
}

\author{
Terri R. Lituchy, CETYS Universidad, Mexicali, Mexico \\ Eduardo R. Díaz, CETYS Universidad, Tijuana Mexico \\ Francisco Velez-Torres, CETYS Universidad, Mexicali, Mexico
}

\section{Introduction}

This paper presents the results of interviews with local and expatriate leaders in Mexico. They believe that transformational leadership behaviors achieve superior levels of effectiveness, although leader-follower relationships in Mexico tend to be characterized by paternalistic behaviors. The expatriates also noted that transactional leadership was important to avoid misunderstandings regarding priorities and expectations. These insights can help leaders be more effective in this context.

The "D" in the LEAD research project is for diaspora. We broadly define the African Diaspora as anyone with roots going back to the African continent (Lituchy, Ford, \& Punnett, 2013). Previous LEAD research only included the Diaspora in North America and the Caribbean. The current research includes Mexico broadly and will serve as a baseline against which further work specifically on the Mexican African Diaspora can be compared. The African Diaspora in Mexico came from the African slave trade in the early colonial period (16th and 17th centuries) with an estimated 200,000-500,000 slaves coming, mostly from West Africa. Many Africans inter-married with Mexicans and are referred to as "mulatto." Black immigrants also fled to Mexico during the years of slavery in the United States. ${ }^{1}$ We believe that including this population in the LEAD project will add a new dimension.

Guzmán (2006) suggested that research should consider leader characteristics and behaviors that may moderate the degree of influence the leader has on followers in Mexico. Robles Francia, de la Garza Ramos, and Quintero (2008) found that managers in Mexico more frequently engage in practices that involve creating consensus and shared goals, and less frequently in looking outward for new ways of conducting business and innovating. Ruiz, Hamlin, and Esparza Martinez (2014) studied managers and non-managers in Mexico to determine the commonly held conceptions of effective leadership. They concluded that both groups perceived leaders who behaved in a manner consistent with consideration structure were more effective than those who were autocratic.

Over the last 50 years, companies have increased their involvement in international business, making cross-cultural competency an essential element of effective leadership (Conger \& Riggio, 2007). Effective leadership in cross-cultural contexts requires that individuals make a conscious effort to participate in cultural experiences that are consistent with their roles as part of an international organization or management team (Conger \& Riggio, 2007). Cross-cultural leaders operating in Mexico may approach their work through transformational leadership practices, which are characterized by placing the follower at the center of the relationship, which is based on higher order, moral imperatives (Burns, 2010). This approach is consistent with the realities of the leader-follower relationship in Mexico, where the leader tends to place a great deal of confidence on the input of selected followers during the decision-making process (Robles Francia et al., 2008).

In the present study, the insights of local and expatriate leaders in Mexico contribute to the study of effective leadership. Hsieh (2010) noted that the opportunity to gain insights on effective leadership is moderated by national, group, and organizational culture is a worthy effort. This approach guides our research. For the first part of the study, presented here, we are interested in examining insights of the local Mexican leadership style, how this is similar to or different from that of other countries, what leadership style is perceived as most effective in Mexico, and the leadership challenges encountered in Mexico. In future research, we will interview and survey the diaspora population in Mexico to get their insights on effective leadership.

This study contributes to the work developed by others that extended research efforts beyond the African context to another culture (Ward, Brown, \& Kiruswa, 2015). By helping to 
close the research gap in leadership and culture, multinational organizations and international managers can better prepare to influence followers and create favorable working environments (Javidan, Dorfman, De Luque, \& House, 2006). The study represents an extension from the LEAD project that will be expanded to the Mexican African Diaspora in the future.

\section{The Current Study}

Three local Mexican leaders and five expatriate leaders working in multinational companies in Mexico were recruited for this study. All leaders have other professionals working under them and have an international exposure of at least two years. The companies were multinationals in the medical, automotive, aerospace and electronics sectors. The five expatriates or outsiders were from different countries: Colombia, Honduras, India, South Korea, and the United States of America. There were two women, and ages ranged from 30 to 48 years. The three local leaders or insiders worked in educational, aerospace, and electronics fields, at multinational companies, and at a university with a highly international orientation; ages ranged from 39 to 63 .

The participants were recruited through professional networks. Each participant received an e-mail invitation with general description of study. Those who expressed interest in participating received a phone call to provide them with more detail regarding the nature of the study. It was made clear that participation was voluntary and that their identities would be kept confidential. If they agreed, one of the researchers met with each participant at a mutually convenient time and place. The interviews were conducted in Spanish for local leaders and English for expatriate leaders. The researcher recorded responses using pen and paper, or a computer. The transcripts were then translated into English when necessary. The interview was composed of open-ended questions that assessed effective leadership styles in Mexico, as well as the differences and similarities between local and expatriate leaders. The leaders were also asked to comment on the challenges they have faced, and to make recommendations for leaders on how best to lead in the Mexican context. The data were transcribed, content-coded, and analyzed.

\section{Results and Discussion}

The expatriates, or outsiders, see the Mexican culture as one in which leading needs to be in a non-aggressive, "friendly" manner. While they recognize the teamwork and innovation orientation of the Mexican culture, they also refer to it as a "vertical" culture; hierarchy is salient in organizations. This particular aspect is so important according to the interviewees, that, as one of them stated, "This may lead to more bureaucracy within companies." While they recognize people are generally responsible, they also see the priority structure of Mexicans as one where work seems to matter less than family commitments and other personal life.

The outsiders were from different cultural backgrounds, and found leading in Mexico presented different challenges. The Latin Americans find the challenge of adaptation relatively easy, but the Asians find that the management of cost, quality and on-time delivery is something with which they have to struggle. They find it necessary to assign goals and follow up on assignments every day. In addition, the issue of team building, making time to foster relationships, and fine-tuning their leadership approach is a priority for them.

When asked what leadership style is most effective in Mexico, one interviewee said that a technique that has been useful is the "labeling" technique, in which the leader puts a nametag on a person according to the behavior the leader expects from that person. For instance, the leaders might expect a person to be the one to "encourage" the team to find new opportunities for business. Another person said that what matters the most is to keep a balance between "aggressiveness" versus "friendliness." In another instance, an expatriate leader said that it was important to take the time to get to know the team members, and to work together without visibly showing authority. The importance of focusing on results, leading by example and fostering communication were also mentioned.

The advice they would give to someone in a leadership assignment in Mexico can be summed up as: let people know the difference between freedom and autonomy, so that employees understand that they may be given autonomy, but also accountability, and that in any organization people are expected to behave within limits and in accordance with company policies, procedures and culture. As with any challenge related to working with other cultures, executives need to be aware

\section{Table 1: Leadership approach as seen practiced in Mexico}

\begin{tabular}{|c|c|}
\hline Outsiders View & Insiders View \\
\hline Non-aggressive and friendly & Paternalistic with a top down approach \\
\hline $\begin{array}{c}\text { Hierarchy and bureaucracy is salient } \\
\text { in organizations and the culture in } \\
\text { general is "vertical" }\end{array}$ & $\begin{array}{c}\text { Authoritarian and transactional } \\
\text { approaches are most effective }\end{array}$ \\
\hline $\begin{array}{c}\text { Work seems to matter less than } \\
\text { family commitments and other } \\
\text { personal life }\end{array}$ & $\begin{array}{c}\text { Learning the culture is a must, along } \\
\text { with the history and the general context } \\
\text { of the country }\end{array}$ \\
\hline $\begin{array}{c}\text { Flexibility to learn and adapt to } \\
\text { changing situations while getting to } \\
\text { know the team members }\end{array}$ & $\begin{array}{c}\text { Inspirational, committed facilitators of } \\
\text { change, disciplined, seek alliances and } \\
\text { manage conflicts }\end{array}$ \\
\hline
\end{tabular}


of the task at hand and quickly learn and adapt to the new situation. According to the respondents, it is important to get to know the local culture and to adopt good practices that are customarily accepted. Accepting feedback is therefore recommended as well as developing strong relationships with team members. This, in the view of one person interviewed, will lead executives to gain respect and trust from subordinates and that will render the leader's work more effective. Finally, another person said, in a cultural environment such as that in Mexico, it is always important to keep in mind the need for training and career development for employees.

Local leaders, or insiders, perceive the Mexican leadership style as rather paternalistic with a top-down approach in which instructions are given without much participation from the subordinate in the decision making process. All of the insiders interviewed said that the Mexican leadership style is authoritarian and that transactional approaches are most effective for getting people to comply and follow mandates from the top.

When comparing the Mexican leadership style with that of foreign managers they said that, to begin with, foreign leaders appear to have a broader vision of business, particularly when they have been exposed to international assignments. They are more oriented towards teamwork, team decision making and continuous and open communication. More focus and attention is put on costs and productivity. However, they also said that it depends on the country of comparison, for instance, executives from the United States of America executives focus on results, aligning people's activities with the objectives of the organization, and taking into consideration people's opinion to a reasonable extent. Executives from countries such as South Korea also focus on results, but people are not taken much into account when it comes to the decision making process. The most effective leadership style in Mexico, from the insiders' perspective, would be "transformational leadership", in which leaders try to develop other leaders at different levels of the organization. In essence, a leadership that looks for balance between results orientation and people orientation, so that results are obtained through the willing collaboration of people. A summary of leadership styles is presented in Table 1

The interviewees also mentioned that the focus on leadership in Mexico should be in developing local talent to take on higher levels of responsibility by applying situational leadership. In order to achieve this leadership development, education and, more specifically, self-learning, plays a key role, along with an attitude of openness to feedback from those being led. Additionally, for foreigners, learning the Mexican culture is a must, along with the history and the general context of the country. Finally, one local leader interviewed said that leaders need to be inspirational, committed facilitators of change,

\section{Table 2: Practical Recommendations for Executives Leading in Mexico}

\section{Key Recommendations for Leading in Mexico}

1. Determine goals and follow up on assignments every day.

2. Focus on results, leading by example and foster communication.

3. Make time to foster relationships and be open to feedback from team members.

4. Use "transformational leadership", in which leaders try to develop other leaders at different levels of the organization.

5. Develop talent to take on higher levels of responsibility by applying situational leadership.

6. Take advantage of the teamwork and innovation orientation of the Mexican culture.

7. Let people understand when they are given autonomy, but also accountability.

disciplined, seek alliances, and manage conflicts.

\section{Conclusion and Implications}

The current research examined the experiences of eight managers (three local, five expatriates) who have led their organizations successfully in Mexico. The findings, summarized in Table 1 above, suggest that both outsiders and insiders identify the hierarchical top down nature of the Mexican culture. Local leaders believe that individuals in Mexico respond favorably to a transformational leadership approach, with both a task and people orientation. The leader-follower relationship needs to be based on clearly understood roles. The expatriates felt that relationships were important, but that it is relatively easy for subordinates in Mexico to lose sight of their work responsibilities and dedicate more time to family or social commitment, thus it was necessary to enact more transactional roles.

As a result of this study some practical recommendations for leading in Mexico are presented (see Table 2). Taken from the considerations of both outsiders and insiders, what is essential is the relationship orientation focusing on developing the people towards higher levels of task complexity and responsibility, while keeping close follow up on organizational objectives.

The results from this study are consistent with earlier LEAD research in other Diaspora countries including Canada, USA, and the Caribbean (Galperin, 2017; Galperin, et al., 2014; Holder et al., 2014). For example, in the Caribbean, effective leaders are transformational, results oriented, and transactional to motivate others and lead by example. Our results are also consistent with the insider and outsider paper in Africa presented in this issue, which reported that local African leaders (see Table 3) believe effective leadership includes authoritarian and transactional leadership styles as well. 
Consistent with the Mexican study, expatriate leaders working in African countries found a mixed leadership style is most appropriate. They must adopt a participatory style and engage subordinates in some situations, but, leaders must also give direction and closely monitor subordinates.

Further research is needed in Mexico and other Latin American countries, and specifically focusing on the African Diaspora. This study provides initial insights on effective leadership that may be used towards advancing cross-cultural leadership theory and informing managers regarding effective leadership styles in Mexico. These results also provide a Mexican baseline that will inform future research focusing on the African Diaspora in Mexico.

\section{Table 3: Comparison on Mexican and African Effective Leadership Styles}

\begin{tabular}{|c|c|}
\hline Mexican Insiders View & African Insiders View \\
\hline $\begin{array}{c}\text { Paternalistic style with a top down } \\
\text { approach is effective }\end{array}$ & $\begin{array}{c}\text { Be firm, dictate work, command } \\
\text { people...is effective }\end{array}$ \\
\hline $\begin{array}{c}\text { Authoritarian and transactional } \\
\text { leadership styles are effective }\end{array}$ & $\begin{array}{c}\text { Authoritarian leadership } \\
\text { style is most effective }\end{array}$ \\
\hline $\begin{array}{c}\text { Learning the culture is a must, along } \\
\text { with the history and the general } \\
\text { context of the country }\end{array}$ & $\begin{array}{c}\text { Expats should avoid condescending } \\
\text { attitudes that suggest that as a foreign } \\
\text { manager they know better than locals }\end{array}$ \\
\hline $\begin{array}{c}\text { Inspirational, committed facilitators } \\
\text { of change, disciplined, seek alliances } \\
\text { and manage conflicts }\end{array}$ & $\begin{array}{c}\text { Spend time understanding followers' } \\
\text { ideas, problems, and complaints }\end{array}$ \\
\hline & Share a clear vision \\
\hline
\end{tabular}

${ }^{*}$ Not mentioned by the Mexican insiders

\section{Endnotes}

www.mexonline.com/history-blacks.htm

\section{References}

Conger, J. A., \& Riggio, R. E. 2007. The practice of leadership: developing the next generation of leaders. Hoboken, NJ: Jossey-Bass.

Galperin, B. 2017. Leadership in the African Diaspora. In T. R. Lituchy, B. Galperin, \& B. J. Punnett (Eds), LEAD: Leadership Effectiveness in Africa and the African Diaspora. London: Palgrave MacMillan.

Galperin, B., Lituchy, T. R., Acquaah, M., Bewaji, T., \& Ford, D. 2014. Effective leadership and motivation in the African diaspora the case of the United States and Canada. Canadian Journal of Administrative Sciences, 31: 257-269.

Guzmán, S. B. 2006. Reflexiones iniciales para la construcción de un modelo mexicano de liderazgo organizacional. Revista de Psicología del Trabajo y de las organizaciones, 22(2): 203-225.
Holder, K., Knight, N., Punnett, B. J., \& Charles, R. 2014

Culture, leadership and motivation in two Commonwealth Caribbean countries: One look at the African Diaspora.

Canadian Journal of Administrative Sciences, 31: 245-256.

Hsieh, S. 2010. Literature review on global leadership competency. The Journal of Human Resource and Adult Learning, 6(2): 99-109.

Lituchy, T. R., Ford, D., \& Punnett, B. J. 2013. Leadership in Uganda, Barbados, Canada and the United States: Exploratory perspectives. African Journal of Economic and Management Studies, 4(2): 201-222.

Robles Francia, V. H., de la Garza Ramos, M. I., \& Quintero, J. M. 2008. El liderazgo de los gerentes de las pymes de Tamaulipas, México, mediante el inventario de las prácticas de liderazgo. Cuadernos de Administración, 21 (37): 293-310.

Ruiz, C. E., Hamlin, R. G., \& Esparza Martinez, L. 2014. Managerial and leadership effectiveness as perceived by managers and non-managerial employees in Mexico. Human Resource Development International, 17(3): 258-276.

Eduardo R. Diaz (eduardo.diaz@cetys.mx) holds an Ed.D. from City University of Seattle. He is a full-time professor in the School of Business and Administration of CETYS University. He teaches marketing management, management theory, and international business. He founded Borderline PR, a small consulting practice that he ran out of the city of Tijuana, Baja California, Mexico, before he entered the education industry full-time.

Terri R. Lituchy (terrilituchy@yahoo.com) holds a Ph.D., University of Arizona and is PIMSA Distinguished Chair and Professor, CETYS Universidad (Mexico). She has taught around the world and published extensively in international journals. Dr. Lituchy has received awards and grants, from SAMS, SHRM, SSHRC, Emerald Publishing, McMaster, Concordia, and University of the West Indies. Books include Successful Professional Women of the Americas, Gender and the Dysfunctional Workplace, Management in Africa, and LEAD.

Francisco Vélez Torres (francisco.velez@cetys.mx) holds a DBA from CETYS University. He is the Dean of the College of Business and Administration, CETYS University, in Baja California, Mexico. Dr. Vélez was previously Director of Graduate Business Programs at CETYS. His field of interest is in planning, strategy leadership and competitiveness. His current research is on locational determinants of foreign direct investment, cluster analyses, and effective leadership. 